\title{
UTILIZAÇÃO DOS DADOS DO GRACE PARA CARACTERIZAÇÃO DA VARIABILIDADE DAS MASSAS DE ÁGUA DO AQÜÍFERO GUARANI
}

\author{
Everton Pereira Bomfim \\ Orientador: Dr. Eder Cassola Molina (IAG-USP) \\ 157 p. - Dissertação (Mestrado) - Defesa 22.11.2006
}

\begin{abstract}
RESUMO. Este trabalho visa estimar a variação da massa de água em um período de dois anos a partir dos dados do GRACE no aqǘfero Guarani; esta variação engloba todas as mudanças de gravidade que são causadas por variações de massas em uma camada fina da superfície da Terra e pela deformação da Terra sólida em resposta a estas variações de massa, e que aqui estão sendo estimadas pelos coeficientes de Stokes fornecidos pela missão GRACE. Foram utilizados os dados do produto do campo de gravidade calculado pelo GFZ em Potsdam na Alemanha, na forma de coeficientes do geopotencial do campo de gravidade estático, estimados apenas pelos dados dos satélites GRACE. As soluções foram obtidas somente a partir de perturbações de órbita de satélites e independentemente de dados de gravidade na superfície oceânica e continental. Os dados das soluções mensais do geóide fornecidas pelo GRACE, considerando $\mathrm{I}=\mathrm{m}=120$ (abril/2002 a novembro/2003 $\mathrm{e} \mathrm{I}=\mathrm{m}=150$ (fevereiro/2003 a julho/2004), foram processados e geraram grades de altura geoidal e anomalia ar-livre para cada conjunto destas soluções mensais, juntamente com os erros associados. Uma inversão linear 3-D da altura geoidal residual do geóide foi realizada para obter a distribuição de densidades tridimensional associada, verificando assim a viabilidade do uso dos dados de GRACE na investigação da variação das massas de água no aqüiffero Guarani. A partir da anomalia ar-livre e dos dados de um modelo topográfico digital da região obteve-se também a anomalia Bouguer em um perfil representativo do aqǘfero, a fim de estimar a variação de massa de água na região analisada.
\end{abstract}

ABSTRACT. This work estimates the variation of the water mass in a period of two years using the GRACE data in the Guarani aquifer; these changes are the sum of all the gravity changes that are caused by variations of masses in a thin layer of the surface of the Earth and by the deformation of the solid Earth in response to these mass variations. These effects are evaluated by using the Stokes coefficients supplied by the GRACE mission, calculated by the GFZ in Potsdam, Germany, in the form of geopotential coefficients of the static gravity field, estimated only by using the GRACE satellite data. The solutions have been calculated only from the disturbances of the satellite orbits and do not depend on the gravity data available in the oceanic and continental areas. The calculations of the geoid monthly solutions by using the GRACE data, considering $\mathrm{I}=\mathrm{m}=120$ (April/2002 to November/2003) and I = $\mathrm{m}=150$ (February/2003 to July/2004), have been transformed in geoidal height and free-air anomaly grids, with respective associated errors. A linear 3-D inversion using the residual geoid height supplied the three-dimensional density distribution, showing that the use of the GRACE data in investigation of the water mass variability in Guarani aquifer is feasible. A Bouguer anomaly profile, calculated by using the GRACE free-air anomaly and a digital topographic model data, was used in order to estimate the water mass variation in the Guarani aquifer region. 